\title{
田
}

\section{A PREVIDÊNCIA SOCIAL NO BRASIL: UMA POLÍTICA EM REESTRUTURAÇÃO}

\author{
SOCIAL SECURITY IN BRAZIL: \\ A POLICY IN RESTRUCTURING
}

Flávia Rebecca Fernandes Rocha'

\section{RESUMO}

Este artigo tem como objetivo visibilizar o processo de reestruturação restritiva de direitos que vem redefinindo a previdência social, desde a década de 1990, sob o argumento de um suposto déficit financeiro, mas que tem como pano de fundo a mercantilização do direito em tempos de crise estrutural do capital e ajuste fiscal do Estado. O artigo apresenta parte da discussão realizada na dissertação de mestrado e tem como metodologia a pesquisa bibliográfica e documental, de natureza qualitativa. A partir da investigação, verifica-se que uma das chaves para a compreensão dos processos de privatização da previdência e a consequente reestruturação da previdência pública está na mundialização do capital, devido à necessidade de apropriação do fundo público pelo capital e de criação de novos nichos de mercado para investimento privado.

Palavras-Chave: Previdência Social. Reestruturação. Direito.

\section{ABSTRACT}

This article aims to make visible the process of restructuring restrictive rights that has been redefining social security, from the 1990 s on the grounds of an alleged financial deficit, but whose background the commodification of the right to time structural crisis of capital and state fiscal adjustment. This article presents part of the discussion held at the Master's thesis and its methodology the bibliographical and documentary research. From the research, it turns out that one of the keys to understanding the processes of privatization of social security and the consequent restructuring of public pensions is in the

1 Assistente Social e Mestre em Serviço Social, Trabalho e Questão Social da Universidade Estadual do Ceará (UECE). 


\section{temporollis}

capital of globalization, due to the need for appropriation of public funds by capital and create new niches market to private investment.

Keywords: Social Security. Restructuring. Right.

Submetido: 03/09/2015.

Aceito: 31/11/2015.

\section{Introdução}

A previdência social é uma das políticas estruturantes do Estado de Bem-Estar Social, nas suas versões clássicas, e também nos países de estrato dependente e periféricos mais desenvolvidos. Seu financiamento repousa sobre importantes frações da mais-valia produzida pelo trabalho em escala social, recolhida na forma de impostos e contribuições. Constitui, pois, um território socialmente delimitado pela luta das classes trabalhadoras que fez gravar nos textos constitucionais e legislações infraconstitucionais o direito à proteção pecuniária na velhice e em caso de invalidez para o trabalho. Lançando mão de importante fração do fundo público e tendo seu território muito bem delimitado por regramentos que não se ligam imediatamente, senão indireta e mediadamente, com a "valorização do valor", essa política passou a exercer excepcional poder de sedução sobre o capital em geral, e o capital financeiro em particular, no tempo presente, marcado por uma crise estrutural.

Com base nesta compreensão, este artigo tem como objetivo apresentar a evolução histórica da proteção social garantida pela política de previdência social no Brasil até o seu coroamento com a conquista da seguridade social e posteriormente demonstrar o seu processo de desmonte, por meio de uma reestruturação destitutiva de direitos da classe trabalhadora, que atende aos interesses do capital, que vem lucrando com os novos espaços de comercialização ao transformar uma política pública em uma mercadoria, vendida como plano de previdência privada.

\section{A construção da proteção social brasileira até seu coroamento com a conquista da seguridade social}

Os sistemas de proteção social se estruturaram no capitalismo no contexto fordista/keynesiano sob condições de acesso do trabalho

2 Para Marx a "valorização do valor" é a circulação do dinheiro como finalidade em si mesma, ou seja, um movimento que torna dinheiro em capital. O objetivo da circulação do dinheiro é o capital como valorização do valor. 
assalariado. Para Silva (2012, p. 446), “[...] a generalização do trabaIho assalariado, com rendimentos elevados, foi determinante para a consolidação dos sistemas de proteção social, que tinha a seguridade social como eixo e o trabalho como via de acesso."

Esses sistemas foram desenvolvidos para atender aos interesses dos trabalhadores, mas também às necessidades de acumulação e legitimação do capital, em um contexto do capitalismo industrial fordista, tensionado pela correlação de forças estabelecida pela luta de classes.

As políticas sociais são concessões/conquistas mais ou menos elásticas a depender da correlação de forças na luta política entre os interesses das classes sociais e seus segmentos envolvidos na questão. No período de expansão, a margem de negociação se amplia; na recessão, ela se restringe. Portanto, os ciclos econômicos, que não se definem por qualquer movimento natural da economia, mas pela interação de um conjunto de decisões ético-políticas e econômicas de homens de carne e osso, balizam as possibilidades e limites da política social. (BEHRING, 2009, p. 315-316).

Desta forma, será apresentado nas linhas abaixo como essas conquistas, permeadas pela correlação de forças das classes sociais envolvidas naquele momento histórico, foram estruturadas no Estado brasileiro, para posteriormente, entender o seu atual processo de desmonte.

As primeiras garantias previdenciárias brasileiras de maior relevância foram alcançadas em 1923, pelo Decreto-lei n. 4.682, Lei Eloy Chaves, o qual criou as primeiras Caixas de Aposentadorias e Pensões, conhecidas como CAPs. Mesmo que de modo bastante tímido, esta lei obrigava as empresas responsáveis pelas estradas de ferro a instituírem as Caixas de Aposentadorias e Pensões, garantindo aos trabaIhadores assalariados do setor urbano o direito ao atendimento médico, ao medicamento, à aposentadoria (ordinária ou por invalidez) e à pensão em caso de morte. Essas Caixas eram de natureza privada e organizadas por empresa.

No entanto, foi a partir de 1930, no governo de Getúlio Vargas (1930-1945; e 1950-1954), que o Estado passou a intervir mais direta e regularmente na organização econômica e social, e emergiu uma tendência de definição de termos do modelo de proteção social. Em 


\section{temporollis}

1933, o governo Vargas criou outra modalidade de instituição previdenciária, os Institutos de Aposentadoria e Pensões (IAPs), com financiamento tripartite. Eles se diferenciavam das CAPs por diversos motivos. "A principal diferença era sua natureza jurídica, que era pública, e não privada. Enquanto as CAPs eram de responsabilidades de cada empresa, os IAPs eram criados pelo Estado e organizados por categoria profissional, aglutinando trabalhadores de várias empresas." (BOSCHETTI, 2008, p. 21).

A expansão do Estado social brasileiro também foi influenciada pelo desenvolvimento dos sistemas de proteção social da Europa, após a $2^{\mathrm{a}}$ Guerra Mundial. O Plano Beveridge, apresentado ao parlamento do Reino Unido em 1942, consagrou um novo conceito, o de seguridade social, considerado oposto à lógica do seguro bismarckiano instituído na Alemanha entre 1883 e 1889 . O relatório foi elaborado por uma comissão presidida pelo lorde William Beveridge, que ficou responsável pela formulação da proposta para um dos pilares do Welfare State da Inglaterra; uma inovação, de fato, por ser um plano nacional unificado e conter um eixo distributivo, ao lado do contributivo.

O Brasil, entretanto, seguiu a lógica do seguro bismarckiano por um longo período, com uma expansão assimétrica da previdência. O sistema previdenciário estatal que se instaurou através dos Institutos de Aposentadorias e Pensões (IAP) era dividido por categorias profissionais e com benefícios diferenciados, passando a ser importante pauta de reivindicação dos trabalhadores a uniformização dos benefícios e serviços prestados pelo sistema previdenciário, além de sua unificação em um organismo único. Estas conquistas só foram alcançadas em 1960, com a Lei n. 3.807, Lei Orgânica da Previdência (LOPS), que uniformizou os benefícios previdenciários e, em 1966, com a criação do Instituto Nacional de Previdência Social (INPS), pelo Decreto-lei n. 72/1966, que unificou os IAPs.

Durante o regime ditatorial (1964-1985) houve uma expansão da cobertura previdenciária, uma estratégia de extensão dos direitos sociais em detrimento dos direitos políticos. Nessa lógica de expansão de direitos e de centralização da gestão, característica dos governos ditatoriais, é que foi criado, em 1977, o Sistema Nacional de Previdência e Assistência Social (SINPAS), pela Lei n. 6.439, coordenado pelo Ministério da Previdência e Assistência Social (MPAS). Seus objetivos foram: formular e propor as políticas de previdência, assistência médica e farmacêutica e de assistência social, bem como supervisionar 
as sete instituições vinculadas ao ministério, atrelando, dessa forma, uma organização funcional às instituições.

Os direitos sociais foram utilizados como uma espécie de compensação pela perda dos direitos políticos e uma maneira de o governo obter a legitimidade necessária à manutenção do regime autoritário. Sob esse ponto de vista, a emergência de garantias sociais no Brasil é comparada à ação do seguro bismarckiano na Alemanha (BOSCHETTI, 2008, p. 70).

Com o fim da ditadura militar, no período de restauração da democracia, a evolução da proteção social vai culminar na criação da seguridade social na Constituição de 1988. Esse novo sistema nasce a partir de um já existente (CAPs, IAPs, INAMPS, LBA), que protegia fundamentalmente os empregados estáveis, fortalecendo sua inclinação beveridgiana por força das pressões sociais que marcaram o processo constituinte, o que resultou na ampliação de sua natureza híbrida:

A seguridade social instituída pela Constituição de 1988, apesar de apresentar caráter inovador e intencionar compor um sistema ou um padrão amplo de direitos sociais, acabou se caracterizando como um sistema híbrido, que conjuga direitos derivados e dependentes do trabalho (previdência) com direitos de caráter universal (saúde) e direitos seletivos (assistência). (BOSCHETTI, 2004, p. 113114).

A palavra seguridade é entendida como um conjunto de seguranças sociais que uma sociedade, de forma solidária, garante a seus membros. O significado da seguridade social na Constituição de 1988 é expressão da correlação de forças que se estabeleceu naquele contexto singular e histórico do Brasil, que mesmo tendo que absorver as proposições do grupo conservador, conseguiu guardar parte das reivindicações dos trabalhadores e da população. E isso pode ser visualizado durante o processo constituinte. ${ }^{3}$

É no interior de um processo de disputas políticas que o capital incorpora as exigências do trabalho. É no leito das lutas ofensivas dos trabalhadores e da ação reativa do capital, que os sistemas de seguridade social são incorporados na ordem capitalista como mecanismos potencialmente funcionais ao processo de acumulação da hegemonia. (MOTA, 1995, p. 131).

3 Para compreender melhor esse processo verificar Boschetti (2008). 


\section{temporollis}

\section{Previdência como direito ou como mercadoria? os caminhos da sua reestruturação no Brasil}

O sistema previdenciário brasileiro comporta os regimes básicos e complementares. Os regimes básicos, de filiação compulsória, são: o Regime Geral de Previdência Social (RGPS), para os trabalhadores da iniciativa privada, atualmente gerido pelo Instituto Nacional do Seguro Social (INSS), autarquia federal vinculada ao Ministério da Previdência Social, criado pelo Decreto n. 99.350, em 1990; e os Regimes Próprios de Previdência de Social (RPPS), para servidores ocupantes de cargos efetivos e militares.

Os regimes complementares são de ingresso facultativo; comportam os seguros privados na modalidade aberto, as Entidades Abertas de Previdência Complementar (EAPC), para qualquer trabalhador que deseja complementar sua aposentadoria; ou fechado, as Entidades Fechadas de Previdência Complementar (EFPC), para trabalhadores específicos de uma empresa ou instituição, também conhecidos como Fundos de Pensão.

Segundo Granemann (2006), "[...] os planos de aposentadoria oferecidos pelas diferentes formas de previdência privada têm um espectro de alternativas bastante limitadas no mundo todo." Basicamente, eles podem operar por Benefícios Definidos, por Contribuição Definida, ou um Misto dos Dois, e este é um critério importante para diferenciar os diversos planos de previdência complementar.

O "Benefício Definido" promete a garantia de uma aposentadoria mensal com base em um montante pré-definido no momento do trabalho e relaciona-se, fundamentalmente, com o lugar do trabaIhador no espaço produtivo, isto é, vincula-se aos salários do trabalhador ao longo de sua vida laborativa.

Os planos de aposentadoria por Contribuição Definida foram criados pelo artigo 401 (K) do Código Americano de Impostos de 1978. Com a instituição de tais planos a contribuição dos trabalhadores é feita em uma conta individual e o resultado das aplicações realizadas ao longo de sua vida produtiva será conhecido no momento da aposentadoria. Se os investimentos lograram sucesso haverá uma substantiva aposentadoria; mas, na ocorrência do contrário, isto é, se a gestão de seus 'ativos' não tiver ob- 


\section{tempordils}

tido sucesso o trabalhador poderá não ter aposentadoria. Nestes planos os trabalhadores são 'incitados' a aplicar o máximo de valores em operações as mais arriscadas para esperar uma aposentadoria a mais elevada possível, daí que as carteiras de aplicações destes planos são quase que majoritariamente em ações e fundos de renda variável. (GRANEMANN, 2006, p. 32).

Segundo a autora, nos planos de Benefício Definido os riscos são em geral divididos pelo capital e pelo trabalho se a referência for a contribuição de ambos. Se o plano é por Contribuição Definida os riscos de não se ter aposentadoria ao final de uma vida de trabalho serão inteiramente assumidos pelo trabalhador.

Conforme apontado por Granemann (2006, p. 34):

[...] não há que se fazer enorme esforço para compreender que, antes cedo do que tarde, o capital viu-se emaranhado no seu próprio argumento já que o Benefício Definido fora uma espécie de atrativo aos trabalhadores quando de sua criação. Mais uma vez a criatura volta-se contra o criador que deve extingui-la rapidamente.

A solução para o crescimento e consolidação dos mercados de capitais inverteu-se em responsabilidades para o capital, que exigiu reformas mais alongadas do que as efetuadas nos limites da previdência social.

A solidariedade da previdência social pública é um entrave para o êxito da previdência privada, pois ela, em si mesma, não tem como produzir aposentadorias em médias muito mais elevadas do que o faz a previdência social. Sua importância reside, então, no papel que a previdência privada desempenha nos mercados de capitais e, especialmente, nas especulações financeiras que têm propiciado e financiado ao redor do mundo, beneficiando de forma majoritária os interesses do capital.

A instituição da previdência privada fechada no Brasil realizouse na década de 1960, década seguinte à implementação nos EUA (1950). Primeiramente, a previdência privada foi implementada sob a forma de fundação de seguridade e, somente na década de $1970 \mathrm{im}$ plementada como fundo de pensão, este irá se desenvolver de modo importante a partir de 1990.

A construção da previdência privada no Brasil foi obra de

Temporalis, Brasília (DF), ano 15, n. 30, jul./dez. 2015. 


\section{temporollis}

interesse da burguesia estrangeira e local e das altas patentes militares dirigentes das empresas estatais brasileiras. Expressam uma clara confluência entre os objetivos de diferentes frações do capital: os capitais imperialistas, estatal e privado nacional na construção de um novo estágio do desenvolvimento do capitalismo monopolista, o financeiro (GRANEMANN, 2006, p. 176).

A previdência privada não se põe como solução para a previdência pública, mas como a razão mesma de sua fragilização. No Brasil, baliza o crescimento da previdência privada a aprovação da Lei ${ }^{\circ}$ 6.435, de 1977, bem como das alterações consoante a Lei n. 6.462/1977 e os Decretos n. 81.240 e $n^{\circ} 81.402$, de 1978, conformando o marco legal inicial necessário à expansão da previdência privada no país. Respectivamente, o primeiro decreto regulamenta as entidades fechadas e o segundo as entidades abertas de previdência privada.

Fiel ao papel de organismo empenhado na defesa do modo de produção capitalista, na sua expansão e em saídas para as crises do capital é que o Banco Mundial passa a elaborar uma política de intervenção internacionalmente articulada para a previdência social, mais especificamente para o seu desmonte enquanto política pública e para a construção de um aparato privado de previdência. A tais intervenções esta agência internacional do capital denominou de "reformas da previdência", que Behring (2008) irá denominar de "contrarreforma", pois retiram diretos da classe trabalhadora.

A mais significativa referência para a difusão da política de privatização da previdência social e orientadora das "contrarreformas" necessárias ao estágio atual da acumulação está centrada em duas publicações do Banco Mundial, o documento de 1994 e de 2005, tratando da "teoria dos pilares".

Os argumentos centrais dos documentos do Banco Mundial articulam-se em dois eixos-diagnósticos: o envelhecimento demográfico e a falência de numerosos sistemas públicos de aposentadoria, com um suposto déficit da previdência. É com base nesses dois argumentos que se encontra o solo propício para a realização da primeira "reforma" da previdência no Brasil em 1998, sob a lógica da reforma do Estado implementada no governo Fernando Henrique Cardoso (1995-2002).

Esse primeiro processo de reestruturação restritiva de direitos 
da previdência brasileira ocorreu no primeiro mandato do presidente FHC (1995-1998), pela Emenda Constitucional n² 20, em 1998. Essa reestruturação significou a perda de grandes conquistas no campo da proteção social previdenciária. O governo a justificou com a avaliação crítica centrada no desequilíbrio financeiro do sistema, agravado pelas mudanças introduzidas na Constituição Federal de 1988.

Dentre as alterações realizadas pela EC n. 20/1998, a que mais retrata a lógica da "reforma" da previdência é a do princípio da "manutenção do equilíbrio econômico e financeiro", que restou explicitado no caput do art. 201 da Constituição Federal de 1988. Essa medida foi necessária aos interesses do capital para alterar a prioridade do sistema previdenciário em detrimento da proteção social e da solidariedade da política.

Foi com vistas à manutenção deste equilíbrio financeiro e atuarial que se tentou aprovar, na votação da $E C n^{\circ}$ 20/1998, o limite de idade para aposentadoria por tempo de contribuição, no RGPS, não aprovado por apenas um voto. No ano seguinte criou-se um limite de idade disfarçado com o fator previdenciário, pela Lei n. 9.876/1999, com aplicação obrigatória justamente para este benefício.

A referida Lei n. 9.876/1999, conforme afirmou o então ministro da Previdência, deu seguimento à "contrarreforma" e modificou completamente a sistemática de cálculo dos benefícios previdenciários. Alterou o conceito do salário de benefício, contido no art. 29 da Lei n. 8.213/1991, substituindo o cálculo do benefício sobre a média dos trinta e seis últimos salários de contribuição, corrigidos, monetariamente, mês a mês, pela média aritmética simples dos maiores salários de contribuição, correspondentes a oitenta por cento de todo o período contributivo e com correção anual. Essa modificação foi muito prejudicial para a classe trabalhadora, porque, em geral, a média dos trinta e seis últimos salários é financeiramente maior do que a correspondente a oitenta por cento de todo o período contributivo.

Segundo Fortes (2003, p. 188), sobre a discussão da constitucionalidade de praticamente todo o conteúdo da Lei n. 9.876/1999, e, em especial, do fator previdenciário, "foram ajuizadas duas Ações Diretas de Inconstitucionalidades (2.110-9 e 2.111-7), ambas indeferidas pelo Supremo Tribunal Federal por maioria dos votos".

Para o governo, o fator previdenciário visa corrigir o desequi- 


\section{temporollis}

líbrio entre o tempo de contribuição e o tempo de usufruto dos benefícios. É uma resposta à pressão demográfica sobre o sistema e permite considerar o envelhecimento da população no cálculo do benefício consoante a apuração do tempo de "sobrevida". O fator previdenciário inclui critérios combinados entre idade no momento da aposentadoria, tempo de contribuição, esforço contributivo e expectativa de sobrevida, na definição do valor do benefício. Além da introdução de um critério atuarial, o fator previdenciário premiará aqueles que postergarem sua aposentadoria com um benefício maior. É uma forma de individualizar o cálculo do valor do benefício.

O fator previdenciário tornou desvantajosa a aposentadoria por tempo de contribuição com baixa idade, incentivando o adiamento da aposentadoria, pois é progressivamente maior a cada ano de postergação. Sua consequência imediata foi o aumento da idade média de concessão desse benefício e, posteriormente, a redução do valor médio deste tipo de aposentadoria.

Para o segurado que pretender aposentar-se com o tempo mínimo de contribuição, a renda mensal inicial somente corresponderá à média de seus $80 \%$ maiores salários de contribuição caso a ida para a inatividade dê-se a partir dos 60 anos, devido à aplicação da alíquota do fator previdenciário. Deste modo, seria mais vantajosa a filiação ao regime previdenciário para os homens somente a partir dos 25 anos, que, somados os 35 anos de contribuição, atingiriam a "idade ideal", e não aos 16 (idade mínima permitida pela Constituição para o início do trabalho). Ou seja, aqueles que ingressam mais cedo no mercado de trabalho são prejudicados com a mudança, pois quando atingirem o tempo mínimo para aposentadoria terão idade reduzida, o que diminuirá o fator previdenciário e, em decorrência, a renda mensal inicial do benefício.

De tão controverso, o Fator Previdenciário já foi alvo de várias tentativas de extinção. A mais recente estava prevista na Medida Provisória n. 664, de 2014, vetada parcialmente neste quesito pela Presidente Dilma Rousseff (2011 - atual), que em consequência editou a Medida Provisória n. 676, em 17 de junho de 2015, posteriormente aprovada e transformada na Lei $n^{\circ} 13.183$, de 4 de novembro de 2015, instituindo uma alternativa de aposentadoria integral, que consiste na aplicação da "fórmula 85/95", relativa a soma da idade e do tempo de contribuição, conforme explicação detalhada mais à frente. 
Seguindo adiante, Mota (2008, p. 138) e Salvador e Boschetti (2002, p. 128-129) elencam as principais retiradas de direitos promovidas pela "contrarreforma" de 1998, pela EC n²0:

a) A conversão da aposentadoria por tempo de serviço em aposentadoria por tempo de contribuição;

b) Instituição da idade mínima de 48 anos para as mulheres e de 53 anos para os homens para aposentadoria proporcional;

c) $\mathrm{O}$ estabelecimento do teto máximo dos benefícios (hoje em $\mathrm{R} \$ 4.663,75$ ) e a desvinculação desse teto do valor do salário-mínimo;

d) A supressão do cálculo da aposentadoria com base nos últimos 36 salários de contribuição, abrindo espaço para a posterior instituição da Lei nº 9.876/99; peciais;

e) Criação de novas exigências para as aposentadorias es-

f) A instituição do regime contributivo para os servidores públicos;

g) A criação do fator previdenciário;

h) Paridade nas contribuições para fundos de pensão, isto é, a contribuição da patrocinadora não poderá ser maior que a do empregado.

Se em 1998 o governo FHC implementou uma "reforma" modificando substancialmente o Regime Geral de Previdência Social (RGPS) e parte do Regime Próprio de Previdência Social (RPPS), conforme exposto acima; em 2003 o governo Lula deu continuidade ao processo de reestruturação restritiva de direitos da previdência, alterando principalmente o RPPS, que afeta os servidores públicos, conforme a Emenda Constitucional $n^{\circ} 41$, e, posteriormente, com a EC $n^{\circ}$ 47 , de 2005. Também foi o presidente Lula que vetou o fim do fator previdenciário em 2010, que havia sido aprovado pela Câmara e pelo Senado pela Medida Provisória $n^{\circ}$ 475/2009, após diversas mobilizações dos trabalhadores e aposentados.

As mudanças mais substanciais da Emenda Constitucional $n^{\circ}$ 41, em 2003, atingiram os servidores públicos nos RPPS, com a intro- 


\section{temporollis}

dução de contribuição para os inativos sobre aposentadorias e pensões, com alíquota idêntica a dos servidores ativos (incidente sobre o que exceder ao teto do RGPS); fixação de teto para remuneração (incluindo pensão e aposentadorias); introdução de critérios cruzados para aposentadoria (idade, tempo de contribuição, tempo no serviço público e tempo no cargo); perda de direitos na aposentadoria proporcional (para os incluídos na regra de transição); introdução de fator redutor de proventos de $5 \%$ por ano de idade inferior àqueles estabelecidos.

A chegada de um representante da classe trabalhadora ao poder não trouxe tantos benefícios quanto se esperava. Dentre as alterações acima mencionadas, a mais expressiva foi o fim da aposentadoria integral por tempo de serviço no âmbito do RPPS, uma das principais cláusulas do contrato de trabalho entre servidores públicos e seu empregador. Esse direito foi substituído pela opção de associar-se a um fundo de previdência complementar, previsto no Projeto de Lei $n^{\circ}$ 1.992/2007, com a criação da Fundação de Previdência Complementar do Servidor Público Federal (Funpresp) e fixação do limite máximo para a concessão de aposentadorias e pensões igual ao RGPS. Enviado ao Congresso durante o governo Lula, foi aprovado por maioria simples e transformado na Lei $n^{\circ} 12.618$, em 2012, no governo de sua sucessora, a presidente Dilma Rousseff.

Ora, se o empecilho para criar a "poupança capitalizada" dos servidores públicos brasileiros era o direito à aposentadoria integral, este último foi subtraído dos servidores para atender aos interesses do capital. O espaço para crescimento da previdência complementar se fez pela criação e rebaixamento do teto dos benefícios da previdência pública. Quanto menores o teto e os benefícios para a população, maior será o número de trabalhadores que terão de recorrer aos planos de previdência privada na tentativa de complementação das suas aposentadorias.

O ponto de partida desse rebaixamento dos benefícios previdenciários se deu com a não vinculação do seu reajuste ao salário mínimo, desde a Lei n 8.213/1991, ocasionando a sua depreciação ao longo dos anos. A lógica dessa regressividade na Previdência Social foi acentuada em 1998, no governo tucano, por meio da Emenda Constitucional $\mathrm{n}^{\circ} 20$, em que foi fixado o teto da Previdência, no valor de $\mathrm{R} \$ 1.200,00$, que equivalia a dez salários mínimos, destinados aos trabalhadores regidos pelo Regime Geral de Previdência Social (RGPS). 
Em 2004, no governo Lula, o teto do RGPS foi restabelecido para o equivalente a dez salários mínimos, atualizado para o valor de R\$2.400,00, conforme o artigo $5^{\circ}$ da Emenda Constitucional $n^{\circ} 41 / 2003$. Isto porque há uma tendência de defasagem do valor do teto de contribuições, que não é reajustado conforme a inflação anual, como pode ser verificado na Tabela 1, elaborada com base no histórico de informações do site do Ministério da Previdência Social.

Tabela 1: Evolução dos valores do teto de contribuição e do salário mínimo

\begin{tabular}{|c|c|c|c|c|c|}
\hline Ano & $\begin{array}{c}\text { Teto de } \\
\text { Contribuição } \\
\text { RGPS }\end{array}$ & $\begin{array}{c}\% \text { de } \\
\text { Reajuste }\end{array}$ & $\begin{array}{l}\text { Salário } \\
\text { Mínimo }\end{array}$ & $\begin{array}{c}\% \text { de } \\
\text { Reajuste }\end{array}$ & $\begin{array}{c}\text { Relação Teto/ } \\
\text { Salário } \\
\text { Mínimo }\end{array}$ \\
\hline $\begin{array}{l}\text { Teto } \\
\text { base } \\
2004\end{array}$ & $\mathrm{R} \$ 2.400,00$ & - & $R \$ 240,00$ & - & 10 \\
\hline 2004 & $R \$ 2.508,72$ & $4,53 \%$ & $R \$ 260,00$ & $8,33 \%$ & 9,65 \\
\hline 2005 & $\mathrm{R} \$ 2.668,15$ & $6,36 \%$ & $R \$ 300,00$ & $15,38 \%$ & 8,89 \\
\hline 2006 & $\mathrm{R} \$ 2.801,56$ & $5,00 \%$ & $R \$ 350,00$ & $16,67 \%$ & 8,00 \\
\hline 2007 & $R \$ 2.894,28$ & $3,31 \%$ & $R \$ 380,00$ & $8,57 \%$ & 7,62 \\
\hline 2008 & $R \$ 3.038,99$ & $5,00 \%$ & $\mathrm{R} \$ 415,00$ & $9,21 \%$ & 7,32 \\
\hline 2009 & $R \$ 3.218,90$ & $5,92 \%$ & $R \$ 465,00$ & $12,05 \%$ & 6,92 \\
\hline 2010 & $R \$ 3.467,40$ & $7,72 \%$ & $\mathrm{R} \$ 510,00$ & $9,68 \%$ & 6,80 \\
\hline 2011 & $R \$ 3.689,66$ & $6,41 \%$ & $R \$ 545,00$ & $6,86 \%$ & 6,77 \\
\hline 2012 & $R \$ 3 \cdot 916,20$ & $6,14 \%$ & $R \$ 622,00$ & $14,13 \%$ & 6,30 \\
\hline 2013 & $R \$ 4.159,00$ & $6,20 \%$ & $R \$ 678,00$ & $9,00 \%$ & 6,13 \\
\hline 2014 & $R \$ 4 \cdot 390,24$ & $5,56 \%$ & $R \$ 724,00$ & $6,78 \%$ & 6,06 \\
\hline 2015 & $R \$ 4.663,75$ & $6,23 \%$ & $\mathrm{R} \$ 788,00$ & $8,84 \%$ & 5,92 \\
\hline
\end{tabular}

Fonte: Adaptada pelo autor a partir BRASIL (2015).

Nesse período entre 2004 e 2015, os benefícios do RGPS e o salário mínimo tiveram aumentos diferenciados. O salário mínimo foi reajustado a cada ano, levando-se em consideração a inflação do período anterior e a concessão de ganhos reais, em geral, com base no crescimento real do PIB. Em paralelo, os benefícios previdenciários não obtiveram reajustes muito superiores à inflação do período.

Até o ano de 2015, os percentuais dos reajustes do teto de con- 


\section{temporollis}

tribuição do RGPS foram bem inferiores aos índices aplicados ao salário mínimo. Em razão dessas diferenças, verifica-se, a partir da Tabela 1, que em 2015 o teto de contribuição do RGPS corresponde a apenas 5,92 salários mínimos, e a proporção vem diminuindo a cada ano. Esta foi apenas uma das medidas para retirar o poder aquisitivo do aposentado e induzi-lo a adquirir uma aposentadoria complementar.

A reestruturação restritiva de direitos dos trabalhadores não chegou ao fim, e infelizmente parece estar longe disso! Recentemente, foram editadas pelo Governo Dilma as Medidas Provisórias n 664 e $\mathrm{n}^{\circ}$ 665, em 30 de dezembro de 2014, que foram apreciadas pelo Congresso Nacional e transformadas em leis: Lei Ordinária $n^{\circ} 13.135$ e $n^{\circ} 13.134$, respectivamente. Ambas aprovadas em 16 e 17 de junho de 2015, dando seguimento à "contrarreforma" da previdência social.

A Lei Ordinária n 13.135/2015, originada da MP 664/2014, alterou a legislação que trata do Plano de Benefícios da Previdência Social (Lei $n^{\circ}$ 8.213/1991); da carreira de perícia médica (Lei $n^{\circ}$ 10.876/2004); do Regime Jurídico Único (Lei $n^{\circ} 8.112 / 1990$ ) e da aposentadoria especial ao cooperado de cooperativa de trabalho ou de produção (Lei $\left.n^{\circ} 10.666 / 2003\right)$, trazendo mudanças na pensão por morte; no auxílio-doença; no auxílio-reclusão; na aposentadoria por invalidez; e na perícia médica. Já a Lei Ordinária $\mathrm{n}^{\circ} 13.134 / 2015$, originada da MP $\mathrm{n}^{\circ}$ 665/2014, alterou a legislação que trata do seguro-desemprego (Lei ${ }^{\circ}$ 7.998/1990); do abono salarial (Lei $n^{\circ} 8.900 / 1994$ ) e do seguro-defeso (Lei $n^{\circ} 10.779 / 2003$ ), trazendo mudanças nestes respectivos direitos.

Em linhas gerais, a lógica das Medidas Provisórias transformadas em leis, é a da limitação do acesso aos direitos viabilizados pela previdência pública e a da redução dos valores de benefícios, prejudicando os trabalhadores e favorecendo o capital. No caso da pensão por morte, por exemplo, benefício que sofreu maior impacto nessa "minirreforma" da previdência social, consolidada pela Lei $\mathrm{n}^{\circ}$ 13.135/2015, houve uma série de modificações que retratam a lógica atual, conforme explicação abaixo:

Após a publicação da Medida Provisória 664/2014, convertida na Lei $n^{\circ} 13.135 / 2015$, a pensão por morte no RGPS para cônjuges, companheiros e companheiras passou a ser temporária ou vitalícia, a depender da idade do pensionista no dia do óbito do segurado. Anteriormente, para os citados dependentes, a pensão por morte era vitalícia, vedada a acumulação de mais de uma pensão deixada por 


\section{tempordils}

cônjuge ou companheiro, ressalvada a opção mais vantajosa. A Lei 13.135/2015 em muito modificou a MP 664/2014, as novas regras alcançaram os cônjuges, no entanto, nada mudou para os demais dependentes (filhos e equiparados, os pais e irmãos). Em regra, se o óbito ocorrer sem que o segurado tenha vertido 18 contribuições mensais ou se o casamento ou a união estável tiverem sido iniciados em menos de 2 anos antes do óbito do segurado, a pensão por morte será paga por 4 meses ao cônjuge, companheiro ou companheira, salvo se o óbito do segurado decorrer de acidente de qualquer natureza ou de doença profissional do trabalho. Se o óbito ocorrer depois de vertidas 18 contribuições mensais e pelo menos 2 anos após o início do casamento ou da união estável, ou se então o óbito do segurado decorrer de acidente de qualquer natureza ou de doença profissional ou do trabalho, a pensão terá um período estipulado de duração de acordo a tábua de mortalidade do IBGE, sendo vitalícia apenas se o pensionista tiver 44 anos de idade no dia da morte. (AMADO, 2015, p. 488-489).

Assim, quanto a estas Medidas Provisórias, asseveram Salvador e Silva, (2015, p. 46):

Chama a atenção que o conjunto das medidas atinge principalmente os trabalhadores de baixa renda (os pensionistas, desempregados, pescadores artesanais, e os que ganham até 2 salários mínimos e recebem abono salarial) e com menos capacidade de mobilização. O que revela a profunda contradição entre o discurso governamental de combate à extrema miséria e as medidas adotadas. Os empresários reagiram ao prazo de 30 dias para afastamento das atividades sob responsabilidade de custeio da empresa. Os trabalhadores, por meio das centrais sindicais, também manifestaram descontentamento, em nota elaborada conjuntamente criticando as medidas e exigindo sua revogação. Além disso, são noticiadas pelo menos quatro Ações Diretas de Inconstitucionalidade no Supremo Tribunal Federal contestando as medidas 664 e 665.

A Medida Provisória n 664 também previa o fim do Fator Previdenciário, conforme já relatado anteriormente, entretanto, este ponto foi vetado pela Presidente Dilma, que em contrapartida editou a MP 676/2015, convertida na Lei $n^{\circ} 13.183$, de 4 de novembro de 2015, alterando a Lei $n^{\circ} 8.213 / 1991$, ao incluir o artigo $29-C$, que institui a "Fórmula 85/95", já citada:

Art. 29-C. O segurado que preencher o requisito para a 


\section{temporollis}

aposentadoria por tempo de contribuição poderá optar pela não incidência do fator previdenciário, no cálculo de sua aposentadoria, quando o total resultante da soma de sua idade e de seu tempo de contribuição, incluídas as frações, na data de requerimento da aposentadoria, for:

I - igual ou superior a noventa e cinco pontos, se homem, observando o tempo mínimo de contribuição de trinta e cinco anos; ou

II - igual ou superior a oitenta e cinco pontos, se mulher, observando o tempo mínimo de contribuição de trinta anos.

$\S 1^{\circ}$ As somas de idade e de tempo de contribuição previstas no caput serão majoradas em um ponto. (BRASIL, 1991b) (Grifo nosso).

Assim, a Lei $n^{\circ} 13.183 / 2015$ sacramentou o que foi instituído pela Medida Provisória $n^{\circ} 676 / 2015$, tornando facultativo o fator previdenciário para a aposentadoria por tempo de contribuição, desde que o segurado preencha os requisitos da regra alternativa, intitulada "85/95" que, apesar de utilizar a terminologia "pontos", a intenção da referida lei foi nitidamente cumular os requisitos de tempo de contribuição e idade, de modo a atingir a "regra de aposentadoria ideal". A saber: 60 anos de idade + 35 anos de contribuição, se homem; e 55 anos de idade + 30 se mulher; o que, por sua vez, pode ser traduzido pela "regra de pontos" 95 pontos para o homem e 85 pontos para a mulher. Além disso, a nova lei também prevê que as somas de idade e tempo de contribuição serão majoradas em um ponto, a partir de 2018 até 2026, quando atingirão a "Fórmula 90/100", quando não mais serão favoráveis para nenhum trabalhador.

Diante do exposto, salientamos que grande parte dessa reestruturação previdenciária ocorreu sem socialização de informações de forma clara para a população, e pior, por meio de Medida Provisória. O desconhecimento foi parte da estratégia utilizada para despolitizar a discussão da seguridade e, especialmente, a da previdência social. As armas secretas utilizadas por FHC, Lula e Dilma para conquistar a opinião pública e obter apoio foram a manipulação de uma linguagem técnica; suprimiram informações sobre o uso indevido dos recursos da previdência no saneamento das contas públicas; a sonegação e isenção das contribuições à previdência; e a ditadura do superávit primário. 


\section{Conclusão}

Uma das chaves para a compreensão dos processos de privatização da previdência e a consequente reestruturação da previdência pública está na mundialização do capital, devido à necessidade de apropriação dos fundos públicos pelo capital e de criação de nichos de mercado para investimento privado. É dessa forma que se abrem espaços para o inaudito mercado de venda de serviços sociais, antes âmbito exclusivo do Estado, tendo a previdência social como a principal vítima desse processo devido a quantidade de dinheiro que movimenta, sofrendo "contrarreformas", diminuindo direitos, para induzir os trabalhadores a complementá-los por meio da compra dos planos de previdência privada.

Isso parece explicar a sanha das classes dominantes em realizar "contrarreformas" dos sistemas de previdência pública, que implicam na diminuição de direitos universais derivados do trabalho e abrem espaços para o investimento privado das instituições financeiras numa quadra histórica marcada pela crise estrutural do capital.

O principal argumento utilizado para justificar a reestruturação restritiva de direitos sofrida pela previdência social brasileira tem sido o suposto déficit orçamentário, que não é real se levado em consideração o conjunto de receitas da seguridade social, conforme dados amplamente divulgados pela Associação Nacional dos Auditores-Fiscais da Receita Federal do Brasil (ANFIP). A nota dissonante no financiamento da previdência social está na forma como vem sendo gerida a política econômica, e reflete as opções macroeconômicas adotadas nas últimas décadas, que fragilizaram o mercado de trabalho.

No Brasil, faz-se essencial aumentar o número de contribuintes para o sistema, via inclusão no mercado de trabalho formal do enorme contingente de trabalhadores informais. É o fortalecimento do mercado de trabalho que garantirá dignamente a proteção social em uma sociedade em que $45,4 \%$ dos trabalhadores que fazem parte da População Economicamente Ativa (PEA) não contribuem para a previdência social, conforme dados da PNAD (2011).

\section{Referências}

AMADO, F. Direito previdenciário. 6. ed. Salvador: Editora JusPodivm, 2015. 


\section{temporollis}

BEHRING, E. Brasil em contra-reforma: desestruturação do estado e perda de direitos. 2. ed. São Paulo: Cortez, 2008.

- Política social no contexto de crise capitalista. In: $\overline{B O S C H} E T T I$, I. (Orgs.). Serviço Social: direitos sociais e competências profissionais. Brasília: CFESS; ABEPSS, 2009.

BOSCHETTI, I. Seguridade social e trabalho: paradoxos na construção das políticas de previdência e assistência social no Brasil. Brasília-DF: Letras Livres: Editora UNB, 2008.

- Seguridade social e projeto ético-político do serviço social: que direitos para qual cidadania?. Serviço Social \& Sociedade, São Paulo, n. 79, p. 108-132, nov. 2004.

BRASIL. Constituição da República Federativa do Brasil de 1988. Diário Oficial da União, Poder Executivo, Brasília, DF, 5 out. 1988. Disponível em: <http://www.planalto.gov.br/ccivil_03/Constituicao/ Constituicao.htm >. Acesso em: 21 jan. 2015.

. Emenda Constitucional n²0, de 18 de dezembro de 1998. Modificou o sistema de previdência social, estabeleceu normas de transição. Brasília, Diário Oficial da União, 19 de dezembro de 1998.

. Emenda Constitucional $\mathrm{n}^{\circ} 41$, de 19 de dezembro de 2003. Modifica os artigos 37, 40, 42, 48, 96, 149 e 201 da Constituição Federal, e dá outras providências. Diário Oficial da União, 22 de dezembro de 2003.

. Emenda Constitucional $n^{\circ} 47$, de 5 de julho de 2005. Altera os artigos 37, 40, 195 e 201 da Constituição Federal, para dispor sobre a previdência social, e dá outras providências. Brasília, Diário Oficial da União, 5 de julho de 2005.

- Presidência da República. Medida Provisória $n^{\circ} 475$, de 23.12.2009. Dispõe sobre o reajuste dos benefícios mantidos pela Previdência em 2010 e 2011. Diário Oficial da União, Brasília, seção 1, p. 1, 24 dez. 2009.

. Medida Provisória $n^{\circ} 664$ de 30.12.2014. Altera as Leis $\mathrm{n}^{\circ} 8.213$, de $24.07 .1991, \mathrm{n}^{\circ} 10.876$, de 2.07.2004, $\mathrm{n}^{\circ} 8.112$, de 11.12. 1990, e a Lei $n^{\circ} 10.666$, de 8 de maio de 2003. Diário Oficial da União, 
Brasília, nº 252-A, seção 1, p. 1, 30 dez. 2014a.

. Medida Provisória n 665 de 30.12.2014. Altera a Lei

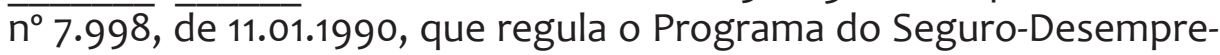
go, o Abono Salarial e institui o Fundo de Amparo ao Trabalhador, altera a Lei $n^{\circ} 10.779$, de 25.11.2003, que trata do seguro-desemprego para o pescador. Diário Oficial da União, Brasília, nº 252-A, seção 1, p. 2-3, 30 dez. 2014b.

. Medida Provisória $n^{\circ} 676$, de 17.06.2015. Altera a Lei no 8.213 , de 24.07.1991, que regula o Plano de Benefícios da Previdência Social. Diário Oficial da União, Brasília, seção 1, p. 1, 18 jun. 2015.

. Lei $n^{\circ} 8.212$, de 24 de janeiro de 1991. Dispõe sobre a

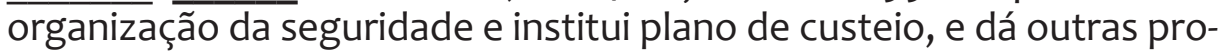
vidências. Diário Oficial da União, n 142, seção 1, p. 121, 25 de jul. 1991a.

. Lei $n^{\circ} 8.213$, de 24 de janeiro de 1991. Dispõe sobre

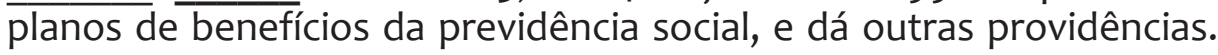
Diário Oficial da União, nº 142, seção 1, p. 121, 25 de jul. 1991b.

. Lei $n^{\circ} 8.900$, de 30 de junho de 1994. Dispõe sobre o benefício do seguro-desemprego, altera dispositivo da Lei $n^{\circ} 7.998$, de 11 de janeiro de 1990, e dá outras providências. Diário Oficial da União, Brasília, seção 1, p. 1, 01 de jul. 1994.

. Lei $n^{\circ} 9.876$, de 26 de novembro de 1996. Dispõe sobre a contribuição previdenciária do contribuinte individual, o cálculo do benefício, altera dispositivos das Leis $n^{\circ} 8.212$ e $n^{\circ} 8.213$, de 1991, e dá outras providências. Diário Oficial da União, Brasília, 27 de nov. 1996.

. Lei $n^{\circ} 12.618$, de 30 de abril de 2012. Institui o regime de previdência complementar para os servidores públicos federais titulares de cargo efetivo; e dá outras providências. Diário Oficial da União, Brasília, 2 de mai. 2012.

. Lei $n^{\circ} 13.134$, de 16 de junho de 2015 . Altera as Leis que regula o Programa do Seguro-Desemprego e o Abono Salarial e institui o Fundo de Amparo ao Trabalhador (FAT); e dá outras providências. Diário Oficial da União, Brasília, 17 de jun. 2015. 


\section{temporollis}

. Lei $\mathrm{n}^{\circ} 13.135$, de 17 de junho de 2015. Altera as Leis

$\overline{n^{\circ} 8.213}$, de 24 de julho de 1991, $\mathrm{n}^{\circ} 10.876$, de 2 de junho de 2004, $\mathrm{n}^{\circ} 8.112$, de 11 de dezembro de 1990 , e $\mathrm{n}^{\circ} 10.666$, de 8 de maio de 2003, e dá outras providências. Diário Oficial da União, Brasília, 18 de jun. 2015 .

. Lei $n^{\circ} 13.183$, de 4 de novembro de 2015. Altera as Leis $n^{\circ} 8.212$, de 24 de julho de 1991 , e $n^{\circ} 8.213$, de 24 de julho de 1991; e dá outras providências. Diário Oficial da União, Brasília, 5 de nov. 2015.

. Decreto-Lei n. 4.682, de 24 de janeiro de 1923. Crea,

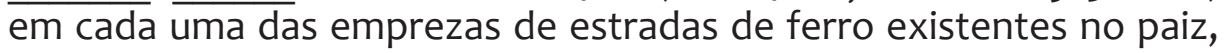
uma caixa de aposentadoria e pensões para os respectivos ernpregados. Diário Oficial da União, Brasília, 24 jan. 1923. Disponível em: < http://www.planalto.gov.br/ccivil_03/decreto/Historicos/DPL/DPL4682. htm> Acesso em: 29 jun. 2015.

. Ministério da Previdência Social. Histórico do valor do salário mínimo e teto para contribuição. 2015. Disponível em: <http://www. previdencia.gov.br/servicos-ao-cidadao/informacoes-gerais/historicovalor-salario-minimo-teto-contribuicao/> Acesso em: 13 set. 2015.

FORTES, S. A reforma previdenciária e seu reflexo na sistemática de cálculo da renda mensal inicial dos benefícios previdenciários. In: ROCHA, Daniel. (Org.). Temas atuais do direito previdenciário e assistência social. Porto Alegre: Livraria do advogado, 2003.

GRANEMANN, S. Para uma interpretação marxista da previdência privada. 2006. 268 f. Tese (Doutorado Serviço Social). Faculdade de Serviço Social da Universidade Federal do Rio de Janeiro. Rio de Janeiro, 2006.

MOTA, A. E. Crônica de uma morte anunciada: as reformas da previdência social brasileira nos anos de 1990 e 2000. In: BRAGA, L.; CABRAL, M. S. (Org.). Serviço social na previdência: trajetória, projetos profissionais e saberes. 3. ed. São Paulo: Cortez, 2008.

. Cultura da crise e seguridade social: um estudo sobre as tendências da previdência e da assistência social brasileira nos anos 80 e 90. São Paulo: Cortez, 1995.

SALVADOR, E.; BOSCHETTI, I. A reforma da previdência social no Brasil 


\section{temporolis}

e os impactos sobre o mercado de trabalho. Serviço Social \& Sociedade, São Paulo, v. 70, p. 114-139, 2002.

; SILVA, M. L. Fundo público e as medidas provisórias nº 664 e 665: a contrarreforma da previdência em curso. Revista Política Social de Desenvolvimento, São Paulo, Ano 3, p 24-47, maio, 2015.

SILVA, M. L. Previdência social no Brasil: (des)estruturação do trabaIho e condições para sua universalização. São Paulo: Cortez, 2012. 


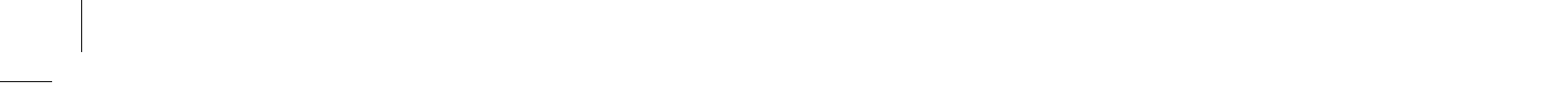

